\title{
KEBIJAKAN HUKUM PIDANA DALAM PENANGGULANGAN KORUPSI BIROKRASI PADA SEKTOR PELAYANAN PUBLIK
}

\author{
Warfian Saputra ${ }^{1}$ \\ Fakultas Hukum Universitas Batanghari Jambi \\ Email: Warfian.koebito@gmail.com
}

\begin{abstract}
Abstrak
Menganalisa dari kebijakan kriminal dan tujuan hukum pidana bahwa pidana bukanlah sekedar pembalasan kepada orang yang telah melakukan tindak pidana namun lebih dari itu bertujuan yang lebih bermanfaat buat kepentingan masyarakat. Disamping itu peradilan kriminal tidak mungkin untuk mencurahkan segala tenaga dan pikirannya pada perkara yang penting kalau bersamaan dengan itu harus meladeni dan menyelesaikan banyaknya perkara yang kecil dan remeh. Sesuai dengan pernyataan di atas, maka permasalahan dalam tulisan ini adalah bagaimana Kebijakan Formulasi Hukum Pidana tentang korupsi birokrasi pada pelayanan publik saat ini dan masa akan datang.
\end{abstract}

Kata kunci: kebijakan hokum, korupsi birokrasi, pelayanan publik

\begin{abstract}
Analyzes of criminal policy and criminal law that criminal purpose is not just a retaliation to persons who have committed criminal acts but furthermore aims to create more useful community interests. In addition, criminal justice is impossible to devote all his energy and his thoughts on an important matter if at the same time having tomeladeni and completing the number of things that are small and insignificant. In accordance with the above statement, then the problems in this paper is how Policy Formulation of criminal law about bureaucratic corruption in the public service at this time and the time will come.
\end{abstract}

Keyword: inform policy, corruption, bureaucracy, public service

\section{PENDAHULUAN}

Pembangunan pemerintahan yang berkelanjutan dalam peningkatan kinerja pada pelayanan publik sebagai ujung tombak pelayanan yang prima pemerintah kepada masyarakat tidak berjalan optimal seperti yang diharapkan dikarenakan masih banyaknya mental aparatur pemerintahan sebagai parasit bagi masyarakat yang selalu mengambil celah keuntungan pribadi dalam melaksanakan tugas sebagai pelayanan publik bagi masyarakat, korupsi dalam birokrasi pada pelayanan publik ini menjadi menjadi masalah yang sangat serius harus segera ditanggulangi, korupsi Birokrasi pada pelayanan publik ini dengan nilai kecil namun masif hampir terjadi pada semua instansi yang dilakukan aparatur pemerintahan dengan berbagai alasan yang tidak mempunyai dasar hukum yang jelas, bagi mereka keuntungan yang didapat menjadi penghasilan tambahan atas imbalan terhadap pelayanan publik yang diberikan masyarakat.

\footnotetext{
${ }^{1}$ Dosen Fakultas Hukum Universitas Batanghari
} 
Begitu banyak peraturan telah dikeluarkan dan begitu banyak himbauan telah disampaikan yang hanya menjadi sebuah kata-kata penghias ruangan tanpa meninggalkan arti apapun beberapa peraturan terkait tentang penanggulangan korupsi diantaranya Undang-Undang 31 Tahun 1999 mengalami perubahan menjadi UndangUndang 20 Tahun 2001 yang dalam hal ini termuat dalam Pasal 12 A, yang tebaru adalah Peraturan Presiden (Perpres) Nomor 87 Tahun 2016 tentang Satuan Tugas Sapu Bersih Pungutan Liar, yang selanjutnya disebut Satgas Saber Pungli dan berbagai peraturan yang dikeluarkan oleh instansi pemerintahan pusat dan pemerintahan daerah maupun turunannya. Yang lebih memfokuskan pada aturan korupsi birokrasi dengan nilai yang kecil namun massif terjadi pada instansi pemerintahan yang memberikan pelayanan publik.

Banyaknya peraturan yang dikeluarkan belum mampu menanggulangi permasalahan korupsi birokrasi pada pelayanan publik tersebut sehingga diperlukan upaya berfikir luar biasa dalam penanggulangan korupsi birokrasi tersebut.

Adapun tujuan dari penelitian ini adalah sebagai berikut:

1. Untuk mendeskripsikan dan menjelaskan gambaran kebijakan formulasi hukum pidana yang sudah ada dalam penanggulangan Korupsi birokrasi.

2. Untuk mendapatkan sebuah kebijakan hukum yang baru mengenai penanggulangan korupsi birokrasi dimasa akan datang.

Mengetahui bekerjanya hukum pidana diwilayah pelayanan publik, maka kita harus mengetahui terlebih dahulu ruang lingkup pelayanan publik tersebut. Pelayanan publik yang merupakan amanat Undang-Undang Dasar Republik Indonesia Tahun 1945. Seperti diamanatkan UU No 25 Tahun 2009, Ruang lingkup pelayanan publik terdapat pada Pasal 5 ayat (4) Pelayanan atas jasa publik sebagaimana dimaksud pada ayat (1) meliputi:

a. Penyediaan jasa publik oleh instansi pemerintah yang sebagian atau seluruh dananya bersumber dari anggaran pendapatan dan belanja negara dan/atau anggaran pendapatan dan belanja daerah;

b. Penyediaan jasa publik oleh suatu badan usaha yang modal pendiriannya sebagian atau seluruhnya bersumber dari kekayaan negara dan/atau kekayaan daerah yang dipisahkan; dan

c. Penyediaan jasa publik yang pembiayaannya tidak bersumber dari anggaran pendapatan dan belanja negara atau anggaran pendapatan dan belanja daerah atau badan usaha yang modal pendiriannya sebagian atau seluruhnya bersumber dari kekayaan negara dan/atau kekayaan daerah yang dipisahkan, tetapi ketersediaannya menjadi misi negara yang ditetapkan dalam peraturan perundangundangan.

Dalam setiap pelayanan publik maka akan selalu berhubungan birokrasi, birokrasi itu sendiri merupakan suatu prosedur atau cara mekanisme kerja dalam suatu instansi tertentu, suatu mekanisme kerja yang dilakukan oleh aparatur pemerintahan dalam melayani masyarakat. Dari proses pelayanan inilah kerap timbul perbuatan-perbuatan yang menyimpang/perbuatan yang bertentangan dengan hukum berupa pungutan uang yang tidak seharusnya dilakukan aparatur negara tersebut kepada masyarakat yang sedang mengurus kepentingan hal tertentu di intansi pemerintahan atau instansi pelayanan publik. Sehingga ada anggapan bahwa disetiap 
birokrasi akan selalu ada korupsi, birokrasi dan korupsi merupakan dua sisi mata uang yang sulit dipisahkan, hal ini .lebih dikenal dengan istilah korupsi birokrasi.

Dalam penyusunan pada peraturan perundang-undangan dengan melakukan pisau analisis dengan Teori Relatif atau Teori Tujuan, yaitu suatu teory mencari dasar hukum pidana dalam menyelenggarakan tertib masyarakat dan akibatnya, tujuan pidana untuk prevensi terjadinya kejahatan. Wujud pidana ini berbeda-beda, yaitu menakutkan, memperbaiki atau membinasakan. ${ }^{2}$

Menurut Teori Relatif atau Teori Tujuan beranggapan bahwa memidana bukanlah untuk memuaskan tuntutan absolute dari keadilan. Pembalasan itu sendiri tidak mempunyai nilai, tetapi sebagai sarana untuk melindungi kepentingan masyarakat. Oleh karena itu, menurut J. Andenaes, Teori ini dapat disebut sebagai“"Teori Perlindungan Masyarakat"(The Theory of social defence). ${ }^{3}$

\section{METODE PENELITIAN}

Sesuai dengan tema yang di angkat maka penulis merasa tepat untuk memilih jenis penelitian deskriptif. Penelitian deskriptif menurut Prasetya Irawan adalah penelitian yang bertujuan mendeskripsikan atau menjelaskan sesuatu hal seperti apa adanya. ${ }^{4}$ Penelitian yang dilakukan untuk menyikap kebenaran dari relitas yang ada berdasarkan fakta-fakta empiris. Peneliti sebagai seorang pencari kebenaran harus menanyakan secara langsung kepada objek yang diteliti dan sang objek memberikan jawaban langsung kepada peneliti yang diteliti tidak saling mempengaruhi.

Hamid S Attamimi menyatakan bahwa ilmu hukum tidak pernah menjadi ilmu normative murni, dan tidak pernah menjadi ilmu social murni, karena hukum berasal dari Das Sollen dan Das Sein. Pada prinsipnya, hukum itu selalu mengandung aspek cita dan realita, atau dengan kata lain hukum mengandung aspek normatif dan aspek empirik. ${ }^{5}$

Demikian pula Bernard Arif Sidharta menyatakan bahwa kegiatan pengembangan ilmu hukum itu selalu melibatkan dua aspek, yaitu kaidah hukum dan fakta (kenyataan masyarakat) dan bahwa dalam proses pengembangannya kedua aspek itu saling betinteraksi dan harus diinteraksikan. ${ }^{6}$

Dari berapa pendapat tersebut bahwa dalam mengkaji hukum selalu akan terlibat dua konsepsi sekaligus, yaitu hukum sebagai gejala normatif menurut paham positivism dan sekaligus hukum sebagai gejala sosial empiris. Yang mengkosepsikan

\footnotetext{
2 Tolib Setiady, Pokok-pokok hukum penintensier Indonesia (Bandung: Alfabeta, 2010), Halaman 55-56

${ }^{3}$ Barda Nawawi Arif \& Muladi, Toeri-Teori dan kebijakan hukum pidana (Bandung: alumni, 2010), halaman16

${ }^{4}$ Prasetya irawan, Materi pokok metode penelitian administrasi (Jakarta : Universitas terbuka, 2006), halaman 49

${ }^{5}$ A. Hamid S Attamimi, Pidato pengukuhan guru besar (Jakarta: Universitas Indonesia, 1992), halaman 18

${ }^{6}$ Bernard Arif Sidharta, Refleksi tentang structur ilmu hukum, sebuah penelitian tentang fundasi kefilsafatan dan sifat keilmuan ilmu hukum sebagai landasan pengembangan ilmu hukum nasional Indonesia (Bandung: Bandar maju, 2000), halaman 193
} 
hukum sebagai suatu gejala sosial yang dapat diamati dalam kehidupan masyarakat, dengan penggunaan teori-teori sosial untuk dapat memahami hukum secara utuh.

\section{HASIL DAN PEMBAHASAN}

Kebijakan formulasi hukum pidana yang sudah ada dalam penanggulangan Korupsi birokrasi.

Bila membahas tentang hukum pidana maka akan meliputi:

a. Tindak Pidana;

b. Pertanggung Jawaban Pidana;

c. Pidana;

Dalam pembahasan terhadap Korupsi birokrasi ini penulis akan memberi batasan hanya kepada Tindak Pidana dan Pidana sebagai analisa terhadap kebijakan formulasi saat ini.

\section{Tindak Pidana}

Penentuan suatu perbuatan sebagai tindak pidana berarti perbuatan tersebut dilarang, dan sepatutnya dikenai sanksi. Ukuran sebagai perbuatan terlarang terkandung sifat tercela pada perbuatan tersebut. Tindak pidana merupakan suatu perbuatan immoral bukan dalam arti benar atau salah, adil atau tidak adil dalam diri seseorang. Dengan demikian bersifat melukai masyarakat, merugikan atau mencelakakan pihak lain.

Dalam masalah tindak pidana dalam hukum positif saat ini kita merujuk pada Pasal 1 ayat (1) KUHP yaitu:

"Tiada suatu perbuatan dapat dipidana kecuali ada kekuatan aturan pidana dalam perundang-undangan yang telah ada, sebelum perbuatan dilakukan”.

Terjemahan pasal tersebut disebut "asas legalitas".

Sebagaimana dikemukakan oleh Feurbach, seorang sarjana hukum pidana Jerman (1775-1833), yang merumuskan asas legalitas dalam bahasa latin, yaitu: ${ }^{7}$

1) Nulla poena sine lege: Tiada pidana tanpa ketentuan pidana menurut undangundang

2) Nulla poena sine crimene: Tiada pidana tanpa perbuatan pidana.

3) Nullum crimen sine poena lehali: tiada perbuatan pidana tanpa pidana menurut undang-undang.

Penentuan adanya suatu tindak pidana yang terdapat dalam KUHP tersebut di atas sejalan sebagaiman pendapat Simons yang menjelaskan strafbaarfeit tersebut sebagai suatu tindakan yang melanggar hukum, karena pembuat telah melanggar suatu larangan atau keharusan dari pembentuk undang-undang. Simons berpendapat bahwa tindak pidana ada apabila suatu perbuatan sudah sesuai dengan isi rumusan undang-undang. Dari sudut pandang di atas maka suatu perbuatan yang dinyatakan sebagai tindak pidana apabila telah menyalahi dan bertentangan dengan undangundang atau dengan kata lain tindak pidana identik dengan melawan undang-undang atau hukum tertulis. Berkaitan pendapat tersebut penulis kembali mempertanyakan dengan tindak pidana korupsi birokrasi yang ada saat ini.

\footnotetext{
${ }^{7}$ Supanto, Kebijakan Formulasi Hukum Pidana ekonomi dalam menghadapi globalisasi ekonomi, (Semarang, PDIH UNDIP, 2008), Halaman 61
} 
Tindak pidana korupsi birokrasi yang dimaksud penulis adalah tindak pidana korupsi dengan nilai dibawah Rp 5.000.000.-(lima juta rupiah) dengan merujuk pada Pasal 12 A ayat (2).

"Bagi pelaku tindak pidana korupsi yang nilainya kurang dari Rp 5.000.000,00 (lima juta rupiah) sebagaimana dimaksud dalam ayat (1) dipidana dengan pidana penjara paling lama 3 (tiga) tahun dan pidana denda paling banyak $\mathrm{Rp}$ 50.000.000,00 (lima puluh juta rupiah)".

Tindak Pidana Korupsi sebagaimana dimaksud pada Pasal 12 A yaitu berupa suatu perbuatan oleh pegawai negeri maupun bukan pegawai negeri, seperti yang tercantum didalam Pasal 5, Pasal 6, Pasal 7, Pasal 8, Pasal 9, Pasal 10, Pasal 11, Pasal 12 Undang-Undang Tindak Pidana Korupsi ini tidak mengatur masalah Kualifikasi delik berupa pelanggaran atau kejahatan. Dari semua perumusan sanksi pidana yang diidentifikasi terdapat pola-pola perumusan ancaman sanksi pidana dan komposisi jenis ancaman pidana yang akan disajikan dalam bentuk table sebagai berikut:

\begin{tabular}{lll}
\hline No & Perumusan Ancaman Pidana & Pasal \\
\hline 1 & Mati & 2 ayat $(2)$ \\
2 & Seumur Hidup/Penjara dan denda & $2(1), 3,12,12 \mathrm{~B}$ \\
3 & Penjara dan Denda & $6,8,9,10,12 \mathrm{~A}(1),(2)$ \\
4 & Penjara dan/atau Denda & $5,7,11,13,21,22,23,24$ \\
\hline
\end{tabular}

Dalam aturan undang-undang tersebut penulis akan lebih memfokuskan pada pasal-pasal tertentu yang dimaksudkan agar lebih mengarah pada korupsi birokrasi pada tataran pelayanan publik yang nominal rupiah bernilai kecil namun dengan dampak yang massif dan besar pada perkembangan korupsi birokrasi tersebut. Seperti yang dimaksudkan pada Pasal yaitu:

Pasal 12 A Undang-Undang Nomor 20 Tahun 2001 yaitu:

Pasal 12 A

(1) Ketentuan mengenai pidana penjara dan pidana denda sebagaimana dimaksud dalam Pasal 5, Pasal 6, Pasal 7, Pasal 8, Pasal 9, Pasal 10, Pasal 11 dan Pasal 12 tidak berlaku bagi tindak pidana korupsi yang nilainya kurang dari Rp 5.000.000,00 (lima juta rupiah).

(2) Bagi pelaku tindak pidana korupsi yang nilainya kurang dari Rp 5.000.000,00 (lima juta rupiah) sebagaimana dimaksud dalam ayat (1) dipidana dengan pidana penjara paling lama 3 (tiga) tahun dan pidana denda paling banyak $\mathrm{Rp}$ 50.000.000,00 (lima puluh juta rupiah).

Menurut penulis Pasal 12 A ayat (2) tersebut memiliki makna penafsiran yang sangat luas, dengan penggunaan kata tindak pidana korupsi yang nilainya kurang dari Rp 5.000.000,00 (lima juta rupiah), hal ini berarti segala bentuk tindak pidana korupsi yang dimasudkan tanpa batas minimal formulasi tersebut memungkinkan segala bentuk tindak pidana korupsi dengan nilai rupiah yang terkecilpun dapat dijerat dengan pasal tersebut.

Dengan luasnya penafsiran tentang tindak pidan korupsi tersebut hal ini akan berdampak pada bertambahnya beban sistem peradilan pidana saat ini, dengan berbagai masalah yang ditimbulkan dalam kelebihan beban sistem peradilan saat ini justru 
dikhawatirkan kebijakan tersebut akan berdampak manjadi suatu factor kriminogen terhadap kebijakan formulasi itu sendiri.

Didalam KUHP disebutkan kualifikasi tentang kejahatan dan pelanggaran namun dalam spesial rules tidak disebutkan apakah perbuatan yang diatur dalam pasal tersebut termasuk katergori pelanggaran atau sebuah kejahatan. Karena dalam aturan tentang kualifikasi pelanggaran atau kejahatan turut menentukan perbedaanya suatu pemidanaan.

Menurut Sudarto :8

a. Rechtdelicten (kejahatan)

Perbuatan yang bertentangan dengan keadilan, terlepas apakah perbuatan itu diancam pidana dalam suatu undang-undang atau tidak, jadi yang benar-benar idrasakan oleh masyarakat sebagai bertentangan dengan keadilan, misalnya pembunuhan, pencurian, delik-delik semacam ini disebut dnegan kejahatan.

b. Wetsdelicten (Pelanggaran)

Perbuatan yang oleh umum baru disadari sebagai suatu tindak pidana, karena undang-undang menyebutnya sebagai suatu tindak pidana, karena undang-undang menyebutnya sebagi delik, jadi karena undang-undang mengancamnya dengan pidana. Missal parker mobil disebelah kanan jalan (mala quia prohibita). Delikdelik semcam ini disebut pelanggaan.

Mengenai perbedaan antara kejahatan dan pelanggaran ini selain penempatannya, di antara lain: ${ }^{9}$

a. Kejahatan merupakan delik hukum (rechtsdelicten) sehingga perbuatan-perbuatan yang dikualifikasikan sebagai kejahatan secara umum memang dianggap sebagai perilaku yang menyimpang atau bertentangan dengan tata hukum, sedangkan pelanggaran pada umumnya baru diketahui merupakan perilaku yang menyimpang atau bertentangan dengan tata hukum setelah adanya undang-undang mengatur demikian;

b. Mengenai ancaman hukumannya, ancaman pidana terhadap kejahatan lebih berat dari pada pelanggaran. Begitu pula jenis pidananya terhadap kejahatan dikenal pidana penjara sedangkan terhadap pelanggran adalah pidana kurungan;

c. Tenggat waktu daluarsa baik penuntutan maupun menjalankan pidana terhadap kejahatan lebih lama dari pada pelanggaran;

Percobaan terhadap pelanggaran tidak dipidana (Pasal 54 KUHP) begitu juga pembantuan terhadap pelanggaran tidak dipidana (Pasal $60 \mathrm{KUHP}$ ).

\section{Pidana}

Kebijakan legislasi yang tercermin dalam produk perundang-undangan selama ini banyak memberikan kesan lebih mengutamakan jenis pidana dalam sistem pemidanaan. Hampir tidak pernah ditemukan dalam suatu perundang-undangan yang tanpa mencantumkan sanksi pidana di dalamnya. Bentuk-bentuk sanksi pidana yang paling banyak ditetapkan adalah pidana penjara, denda dan kurungan. Pencantuman

\footnotetext{
${ }^{8}$ Sudarto, Hukum Pidana I, (Semarang: yayasan Sudarto), halaman 50

${ }^{9}$ Rahmad syahroni rambe, kebijakan formulasi ketentuan pidana terhadap tindak pidana pencurian di Indonesia (Semarang, MIH UNDIP, 2014), halaman 68
} 
jenis sanksi pidana tersebut dapat lihat dalam setiap perundang-undangan, baik yang berkualifikasi tindak pidana umum maupun tindak pidana khusus.

Pendekatan sanksi yang ada saat ini hanya bersifat terbatas dan pada dipidananya para pelaku saja. Dengan kata lain jenis sanksi pidana bila dilihat dari aspek tujuannya lebih mengarah pada "pencegahan orang melakukan kejahatan" bukan bertujuan "mencegah kejahatan itu tidak terjadi". Jadi lebih bersifat individual.

Pemidanaan bersifat individual ini menurut Barda Nawawi Arief ${ }^{10}$ kurang menyentuh sisi-sisi lain yang berhubungan erat secara structural atau fungsional dengan perbuatan (dan akibat perbuatan) si pelaku. Sisi lain yang bersifat structural atau fungsional ini misalnya pihak korban/penderita lainnya dan structural/kondisi lingkungan yang menyebabkan si pelaku berbuat kejahatan.

1. Dari Strafsoort-nya (jenis sanksi pidana)

a. Melihat dari formulasi tersebut pasal yang menjadi fokus kajian penulis pasal 12A ayat (2) menganut sistem komulasi. Sistem komulasi berupa perampasan kemerdekaan/penjara dan denda. Menurut pengamatan penulis pidana denda tidaklah menjadi hal yang mutlak harus dibayarkan, karena pidana denda dapat diganti dengan denda kurungan.

Dilihat dari sistem pidana komulasi sesungguhnya lebih berat dibandingkan dengan sistem komulatif-alternatif. Sistem komulasi suatu sistem tersebut mengharuskan dijatuhinya pidana penjara dan denda secara bersamaan. Sistem ini ditandai dengan rumusan "dan" yang berarti bersifat komulatif dengan ancaman pidana secara bersamaan. Beda halnya dengan sistem pidana komulatif-alternatif yang merupakan suatu pidana di antara dua jenis pokok yang wajib dijatuhkan ialah pidana penjara sebagai yang utama tanpa disertai pidana alternatifnya, namun hakim dapat pula menjatuhkan secara bersamaan dengan pidana denda sehingga bersifat komulatif. Jadi khusus untuk penjatuhan pidana alternatif ini yang jika dibandingkan dengan KUHP sifat penjatuhan pidana alternatif ini hanya ada pada jenis-jenis pidana tambahan. Sitem komulasi- alternatif ini ditandai dengan kata "dan atau" .

Jika kita bandingkan dengan sistem pidana komulasi yang terdapat pada 12 A ayat (2) dengan pidana komulasi-alternatif pada Pasal 5, 7, 11, 13, 21, 22, 23, 24. Akan terlihat perbandingan dengan sistem komulasi pada pasal $12 \mathrm{~A}$ ayat (2) khusus Bagi pelaku tindak pidana korupsi yang nilainya kurang dari Rp 5.000.000,00 (lima juta rupiah), dan kita bandingkan dengan sistem pidana komulasi-alternatif pada ketentuan mengenai pidana penjara dan pidana denda sebagaimana dimaksud dalam Pasal 5, Pasal 6, Pasal 7, Pasal 8, Pasal 9, Pasal 10, Pasal 11 dan Pasal 12 tidak berlaku bagi tindak pidana korupsi yang nilainya kurang dari Rp 5.000.000,00 (lima juta rupiah) hal ini berarti sistem komulasi hanya berlaku pada tindak pidana korupsi dibawah Rp. 5.000.000.- (lima juta rupiah). Hal ini menjadi menjadi suatu ironi bagaimana sistem komulasi yang bersifat berat dengan nilai dibawah Rp. 5.000.000.- (lima juta rupiah) . disisi lain sifat komulasi-alternatif yang lebih ringan dikenakan pada perkara korupsi di atas Rp. 5.000.000.- (lima juta rupiah).

\footnotetext{
${ }^{10}$ Barda Nawawi Arief, beberapa aspek kebijakan penegakan dan pengembangan hukum
} pidana, (Bandung: Citra Aditya Bakti, 1998), halaman 45 
b. Dalam masalah denda: ${ }^{11}$

1) Adanya perluasan penetapan sistem ancaman denda yang meliputi sistem tunggal, Alternatif, Komulatif, Komulatif -Alternatif

2) Adanya peningkatan yang signifikan ancaman jumlah/ukuran pidana denda, baik yang dirumuskan dengan ancaman minimum maksimum maupun maksimum khusus;

3) penetapan waktu yang lebih lama terhadap pidana kurungan sebagai pengganti pidana denda, jika dibandingkan dengan yang ditetapkan KUHP.

2. Strafmaat-nya (lamanya sanksi pidana)

Dari sisi ini kita melihat lamanya pidana penjara, pada Pasal 12 A ayat (2) menyatakan bahwa ancaman hukumannya dengan masimal 3 tahun penjara, hal ini jika dibandingkan dengan Pasal 3 Undang-Undang 31 Tahun 1999 tentang tindak pidana korupsi dengan ancaman minimal 1 tahun penjara dan maksimal 20 tahun penjara maupun pada Pasal 5 Undang-Undang 20 Tahun 2001 Tentang tindak pidana korupsi dengan ancaman penjara paling singkat 1 tahun penjara dan paling lama 5 tahun penjara.

Melihat dari nilai Pasal 12 A ayat (2) dengan nilai korupsi maksimal Rp. 5.000.000 (lima juta rupiah) di ancam hukuman penjara maksimal 3 tahun penjara, dan pada Pasal 3 Undang-Undang 31 Tahun 1999 diancam dengan minimal 1 tahun penjara dan maksimal 20 tahun penjara maupun pada Pasal 5 Undang-Undang No 20 Tahun 2001 dengan nilai korupsi di atas 5.000 .000 (lima juta rupiah) dengan ancaman minimal 1 tahun penjara dan maksimal 5 tahun penjara. Hal ini menjelaskan bahwa lamanya penjara seorang terpidana korupsi dengan nilai dibawah 5.000 .000 (lima juta rupiah) bisa sama hukumannya dengan seorang terpidana di atas 5.000.000 (lima juta rupiah), bahkan bisa tejadi pidana penjara terdakwa korupsi dengan nilai dibawah Rp 5.000.000 (lima juta rupiah) lebih berat hukumannya dari pidana korupsi dengan nilai diatas 5.000.000 (lima juta rupiah).

Disamping itu juga terdapat masalah yuridis yang terjadi antara aturan umum dalam KUHP dengan aturan khusus yang menjadi lex spesialis dalam perkara korupsi. Misalnya:

a. Undang-Undang khusus tidak disertai aturan pemidanaan/penerapannya. Sehingga pidana minimal tidak dapat begitu saja diterapkan hanya dicantumkan perumusan delik. Untuk dapat diterapkan harus ada sub-sistem yang lain mengaturnya, yaitu harus ada aturan pemidanaan/ pedoman penerapannya terlebih dahulu, seperti halnya dengan pidana maksimal khusus. ${ }^{12}$

Dalam kebijakan menyimpang tersebut tidak diikuti oleh pedoman/aturan penerapan yang bersifat khusus. Lebih ironis kebijakan yang menyimpang dalam pidana denda tersebut dilakukan tanpa pola/kriteria yang jelas sehingga berakibat adanya keanekaragaman (ketidakkonsistenan) dalam sistem pidana denda menetapkan jumlah/ukuran maupun pelaksanaan pidana denda.

${ }^{11}$ Dwi Endah Nurhayati, Sistem pidana denda dalam kebijakan legislative di Indonesia, tesis. (Semarang: Program pasca sarjana, 2009), halaman. 255.

${ }^{12}$ Barda Nawawi Arief, Perkembangan sistem pemidanaan di Indonesia (Semarang Pustaka Megister, 2011), halaman. 30. 
b. Dalam undang-undang khusus menetapkan bahwa "pemufakatan jahat" dipidana sama dengan tindak pidananya. "pemufakatan jahat merupakan istilah juridis, sama halnya dengan istilah juridis lainnya, seperti percobaan, pembantuan, dan pengulangan. Namun dalam aturan undang-undang khusus tersebut tidak memberikan dan batasan/syarat-syarat dikatakannya ada "pemufakatan jahat" seperti halnya dalam KUHP Pasal 88, Padahal Pasal 88 ini tidak berlaku umum untuk undang-undang di luar KUHP. ${ }^{13}$

3. Peraturan Presiden (Perpres) Nomor 87 Tahun 2016 tentang Satuan Tugas Sapu Bersih Pungutan Liar, yang selanjutnya disebut Satgas Saber Pungli.

Tentang Perpres Saber Pungli ini adalah suatu hal yang baru yang mana pada "Satgas Saber Pungli berkedudukan di bawah bertanggung jawab kepada Presiden," bunyi Pasal 1 ayat (2) Perpres ini. Menurut Perpres ini, Satgas Saber Pungli mempunyai tugas melaksanakan pemberantasan pungutan liar secara efektif dan efisien dengan mengoptimalkan pemanfaatan personil, satuan kerja, dan sarana prasarana, baik yang berada di kementerian/lembaga maupun pemerintah daerah. Dalam melaksanakan tugasnya, menurut Perpres ini, Satgas Saber Pungli menyelenggarakan fungsi:

a. Intelijen

b. Pencegahan

c. Penindakan

d. Yustisi.

Adapun wewenang Satgas Saber Pungli adalah: a. Membangun sistem pencegahan dan pemberantasan pungutan liar; b. Melakukan pengumpulan data dan informasi dari kementerian/lembaga dan pihak lain yang terkait dengan menggunakan teknologi informasi; c. Mengoordinasikan, merencanakan, dan melaksanakan operasi pemberantasan pungutan liar; d. Melakukan operasi tangkap tangan; e. Memberikan rekomendasi kepada pimpinan kementerian/lembaga, serta kepala pemerintah daerah untuk memberikan sanksi kepada pelaku pungli sesuai dengan ketentuan peraturan perundang-undangan; f. Memberikan rekomendasi pembentukan dan pelaksanaan tugas lain unit Saber Pungli di setiap instansi penyelenggara pelayaan publik kepada pimpinan kementerian/lembaga dan kepala pemerintah daerah; dan g. Melakukan evaluasi pemberantasan pungutan liar.

Suatu pembentukan Perpes ini merupakan tanggapan atas suatu realita yang sangat luar biasa terjadinya korupsi yang sangat merajalela hingga merasuk pada semua lini birokrasi pemerintahan Pusat dan daerah namun disisi lain hal ini juga menambah hutan belantara peraturan perundang-undangan yang ada di Indonesia sehingga menimbulkan tumpang tindih antara peraturan satu dengan peraturan lainnya dan bisa berdampak konflik interest antara aparat penegak hukum sendiri.

Melihat ketentuan dari Hirarki peraturan perundang-undangan dalam Undang-Undang Nomor 12 tahun 2011 pada Pasal 7 ayat 1 yang terdiri atas:

1. UUD 1945;

2. Ketetapan MPR;

3. Undang-Undang/ Peraturan Pemerintah Pengganti Undang-Undang;

${ }^{13}$ Ibid, halaman. 34 
4. Peraturan Pemerintah;

5. Peraturan Presiden;

6. Peraturan Daerah Provinsi dan;

7. Peraturan Daerah Kabupaten/Kota;

Melihat ketentuan diatas bahwa ketentuan Peraturan Presiden mempunyai kedudukan lebih rendah dari Undang-Undang, sehingga apabila bertentangan dengan Undang-undang yang lebih tinggi maka peraturan yang dibawahnya dapat dikesampingkan.

\section{Sebuah gagasan kebijakan hukum yang baru dalam penanggulangan korupsi birokrasi dimasa akan datang.}

Terlalu banyak kebijakan peraturan yang dibuat nyatanya belum mampu menanggulangi korupsi Birokrasi pada pelayanan publik hal ini tentu menjadi evaluasi apakah dengan penggunaan sanksi hukum saat ini efektif dalam penanggulangan korupsi birokrasi pada pelayanan publik. Untuk itu perlu pendekatan yang berbeda dalam menanggulangi hal ini sebagai berikut:

1. Sistem E-Kerja sebagai acuan dalam Pemberian Reward dan Punishment terhadap aparatur sipil negara penyelenggara pelayanan publik.

Performa kinerja dari pemerintah yang meliputi para aparatur pemerintahan, struktur, dan prosedur organisasi serta teknologi merupakan hal yang paling dituntut untuk mendukung proses pelayanan publik. Namun, kenyataannya aparatur pemerintahan tidak responsive terhadap tuntutan dari masyarakat dan memberikan peforma yang lambat.

Penilaian kinerja saat ini yang hanya menggunakan document formalitas tentang kinerja aparatur pemerintahan sangat sulit diukur sehingga sangat subjektif. Penilaian yang ada juga biasanya berdasarkan pada suka atau tidak suka yang menyebabkan karir pegawai tidak terjamin lantaran promosi dan mutasi tergantung subjetifitas pandangan dari atasan. Untuk itu perlunya dibentuk suatu sistem E-Kerja yang merupakan suatu perangkat digital yang memuat data kinerja aparataur pemerintahan yang berbasis Web online, sehingga setiap kinerja dapat didokumentasikan. Dengan adanya sistem ini dapat memberikan informasi kepada atasan secara cepat dan tepat efektifita kinerja, efesiensi jabatan, dan prestasi kerja. Sehingga menjadi acuan dalam memberikan reward dan punishment

2. Mengutamakan pendekatan Punisment sanksi Adminitrasi dari pada sanksi Pidana.

Peranan aparatur sipil negara dalam melaksanakan tugas pelayanan publik dapat di istilahkan " not the gun, the behind the gun" yang dimaksudkan adalah bukan senjata yang penting melainkan manusia yang menggunakan senjata itu hal ini berarti sebaik apapun peraturan yang dibuat namun yang tetap menjalankan adalah manusia untuk itu sangat diperlukannya kesadaran bagi pegawai pemerintah yang bekerja pada sektor pelayanan publik untuk dapat memahami tugas dengan disiplin dan penuh tanggung jawab.

Pidana merupakan suatu alternatif yang seharusnya sebagai upaya hukum terakhir yang diambil apabila segala upaya hukum lain tidak dapat diandalkan dalam menanggulangi suatu bentuk kejahatan inilah yang menjadi istilah “Ultimum Remedium". Penggunaan sanksi pidana dalam penanganan korupsi 
birokrasi ini tentu akan memakan waktu yang lama dan biaya yang besar sehingga antara biaya proses peradilan yang lebih besar dari pada nilai kerugian yang terjadi tentu ini akan menjadi kurang efektif belum lagi sanksi pidana membuat stigmatisasi yang melekad seumur hidup kepada terpidana inilah beberapa hal-hal yang menjadi pertimbangan mengutamakan penggunaan sanksi administrasi untuk penanggulangan korupsi birokrasi yang mana sanksi administrasi adalah sanksi yang muncul dari hubungan antara pemerintah-warga negara dan dapat dilaksanakan tanpa perantara pihak ketiga (kekuasaan peradilan), tetapi dapat secara langsung dilaksanakan oleh pejabat tata usaha sendiri.

Melalui sanksi administrasi dimaksudkan agar perbuatan pelanggaran itu dihentikan sehingga sanksi administratif merupakan instrument yuridis bersifat preventif dan refresif non yudisial untuk mengakhiri atau menghentikan pelanggaran terhadap ketentuan peraturan yang ada.

3. Relevansi teori Reintegratif Shaming dalam upaya pemberantasan korupsi

\section{a. Teori Reintegratif Shaming}

Seperti yang dikutif oleh Pujiyono dalam bukunya Paulus Hadi Suprapno (pemberian malu Reintegratif sebagai sarana non penal penanggulangan Delikuensi anak). Yang menyatakan bahwa Teori pemberian Malu Reintegratif (Reintegratif Shaming) berangkat dari asumsi dasar, "masyarakat yang tinggi kejahatannya, adalah masyarakat yang warganya kurang efektif mencela kejahatan, sebaliknya masyarakat yang rendah kejahatannya adalah masyarakat yang warganya secara efektif bersifat tidak toleran terhadap kejahatan”. Teori ini ditopang oleh dua pilar utama yaitu (a). saling ketergantungan (interdependency) dan (b). komunitarian (communitarianism). ${ }^{14}$ saling ketergantungan dicerminkan bersifat perorangan, didalamnya mencakup keikutsertaan warga masyarakat dalam suatu jaringan kerja di mana di dalamnya mereka merasa tergantung pada warga masyarakat lain dalam rangka mencapai tujuan hidupnya.

Komutarian bersifat kemasyarakatan, artinya di dalam masyarakat warga terikat kuat dalam suatu hubungan saling ketergantungan yang dicirikan adanya saling kepercayaan dan saling membantu. Ikatan "saling ketergantungan itu" merupakan ciri penting dari penguatan loyalitas kelompok dari pada kepentingan individu. Pemberian Shaming merupakan proses sosial tentang pernyataan sikap "pencelaan" pihak lain yang telah menyadari itu. ${ }^{15}$ Hal ini menyadari bahwa sikap masyarakat yang tidak toleran terhadap suatu kejahatan maka masyarakat akan menunjukan suatu celaan kepada individu pembuat kejahatan, sehingga hal ini akan berdampak lebih mendalam dirasakan pembuat kejahatan membuat terusik hati nuraninya akan kesalahan perbuatan yang dilakukannya telah melanggar nilai-nilai dalam kemasyarakatan. Tentunya hal ini dirasakan pemberian pidana secara moral (malu) ini akan jauh lebih efektif sebagai daya tangkal penanggulangan korupsi birokrasi dibandingkan pidana secara formal dalam pencegahan kejahatan.

\footnotetext{
${ }^{14}$ Pujiyono, Kumpulan tulisan hukum pidana (Bandung: Mandar maju, 2007), halaman 28.

${ }^{15}$ Pijiyono ibid, halaman 29
} 
Shaming dapat mengakibatkan dua kemungkinan, satu: kearah munculnya stigmatisasi atas diri pelaku dan yang lain kearah munculnya stigmatisasi atas diri pelaku, dan kedua: munculnya pengintegrasian pelaku kembali kemasyarakat. ${ }^{16}$ Dalam hal ini terdapat perbedaan yaitu pada bagian pertama stigmatisasi sebagai wujud celaan pemberian rasa malu, namun tidak diiringi usaha untuk mendamaikan pelaku dengan masyarakat. Permasalahan ini tentunya membuat dampak pelaku menjadi tersisih dalam kehidupan masyarakat, hal ini bisa berakibat perilaku jahatnya bisa menempel dan menjadi status dirinya. Sedangkan pada bagian dua: suatu usaha pemberian sanksi dalam wujud pemberian rasa malu atas kejahatan yang dilakukan, namun sanksi tersebut diiringi upaya perbaikan perilaku yang dilakukan agar pelaku bisa kembali diterima dalam masyarakat. berikut:

Untuk lebih menjelaskan akan dapat digambarkan dalam ragaan sebagai

INDIKATOR "REINTEGRATIF SHAMING" DAN STIGMATISASI ${ }^{17}$

\begin{tabular}{|c|c|}
\hline REINTEGRATIF SHAMING & STI \\
\hline $\begin{array}{l}\text { a. Celaan, melanjutkan pertalian kasih } \\
\text { b. Upacara pernyataan celaan, diakhiri } \\
\text { upaya penghapusan sifat jahatnya } \\
\text { perilaku. } \\
\text { c. Pencelaan sifat jahatnya perilaku } \\
\text { tenpa pemeberian label pribadi } \\
\text { sebagai penjahat. } \\
\text { d. Penyimpangan dicegah agar tak } \\
\text { menjadi cirri kepribadian pelaku. }\end{array}$ & $\begin{array}{l}\text { a. Pencelaan, rendahkan dan } \\
\text { mempermalukan. } \\
\text { b. Upacara pernyataan pencelaan tanpa } \\
\text { upaya penghapusan sifat jahatnya } \\
\text { perilku. } \\
\text { c. Pemberian label pribadi pelaku tak } \\
\text { sebatas pada perilaku jahat pelaku. } \\
\text { d. Penyimpangan dibiarkan menjadi cirri } \\
\text { kepribadian pelaku. }\end{array}$ \\
\hline
\end{tabular}

Dalam Teori Shaming yang terdiri dari communitarianism dan interdependency. Yang menurut Braithwaite, communitarianism merupakan karakter masyarakat, sedangkan interpendency meruapakan suatu variabel tentang tingkat analisi individual (individual level of analisis). Communitarianism adalah merupakan anti thesis dari individualism, oleh karena itu terdapat tida unsur: (1) intensitas interdependency yang tinggi; (2) saling percaya dan melaksanakan kewajiban timbale balik; (3) unsur kedua ditafsirkan sebagai symbol dari loyalitas kelompok dari pada keuntungan individual. ${ }^{18}$

Suatu perbedaan akan terlihat dalam pemberian Shaming antara masyarakat barat dengan masyarakat Indonesia. Apabila kita melihat dari masyarakat barat yang cenderung individualistic dari pada memiliki karakteristik communitarianism tentunya pemberian Shaming (malu) terhadap individu pelaku kajahatan tentunya tidak akan efektif dikarenakan ideology masyarakat barat yang individualistic, sehingga dalam masyarakat barat

\footnotetext{
${ }^{16}$ Pujiyono ibid, halaman 29

${ }^{17}$ Pujiyono, ibid halaman 30

${ }^{18}$ Pujiyono, ibid, halaman 31
} 
pemberian sanksi lebih cenderung menggunakan aparatur negara dengan hukum yang ketat yang menggunakan pendekatan koersif dan represif.

\section{KESIMPULAN}

Telah banyak aturan kebijakan formulasi hukum yang telah dibentuk dalam upaya penanggulangan Korupsi birokrasi namun masih banyak juga terdapat berbagai penyimpangan yang dilakukan aparatur pemerintahan pusat maupun daerah yang mana aparatur pemerintahan pada pelayanan publik tersebut diharapkan menjadi ujung tombak dalam perpanjangan tangan pemerintah dalam memberi pelayanan kepada masyarakat yang justrunya aparatur pemerintahan tersebut menjadi parasit bagi masyarakat dengan mengambil imbalan beruapa uang untuk keuntungan pribadi atas jasa yang telah diberikan kepada masyarakat diluar ketentuan peraturan yang berlaku.

Peraturan yang adapun banyak terdapat kekurangan sehingga belum optimalnya dalam penanggulangan korupsi birokrasi, setiap aturan hukum yang ada selalu mengedepankan pendekatan hukum pidana sehingga memerlukan proses peradilan yang panjang disertai biaya yang besar bahkan biaya yang dikeluarkan dalam proses peradilan pidana atas Tersangka/Terdakwa/Terpidana jauh lebih besar dibandingkan nilai kerugian yang terjadi, apabila dipaksakan dimasukan dalam proses peradilan pidana justru hal ini akan semakin membenani sistem peradilan pidana yang sudah ada.

\section{Saran}

Diperlukan upaya penanggulangan yang luar biasa dengan menggunakan sistem E-Kerja dalam acuan pemeberian reward dan punishment serta lebih mengedepankan pemberian sanksi administrasi dari pada sanksi pidana dan penggunaan pendekatan Teori Shamming yang merupakan teori dengan menggunakan suatu usaha pemberian sanksi dalam wujud pemberian rasa malu (moral sanction) atas kejahatan yang dilakukan, namun sanksi tersebut diiringi upaya perbaikan perilaku yang dilakukan agar pelaku bisa kembali diterima dalam masyarakat.

Beberapan gagasan kebijakan hukum yang terbaru diharapkan mampu dalam penanggulangan korupsi birokrasi pada pelayanan publik dan membuat aparatur pemerintahan pada pelayanan publik dapat bekrja disiplin serta tanggung jawab karena merekalah cerminan kinerja pemerintah pada masyarakat, dengan pelayanan publik yang baik negara maju masyarakat sejahterah.

\section{DAFTAR PUSTAKA}

Arif, Barda Nawawi., 1998, Beberapa aspek kebijakan penegakan dan pengembangan hukum pidana. Bandung: Citra Aditya Bakti.

2011, Perkembangan sistem pemidanaan di Indonesia. Semarang: Pustaka Megister.

Arif, Sidarta Bernard., 2000, Refleksi tentang structur ilmu hukum, sebuah penelitian tentang fundasi kefilsafatan dan sifat keilmuan ilmu hukum sebagai landasan pengembangan ilmu hukum nasional Indonesia. Bandung: Bandar maju.

Attamimi, A. Hamid S., 1992, Pidato pengukuhan guru besar. Jakarta: Universitas Indonesia. 
Endah, Dwi Nurhayati, 2009, Sistem pidana denda dalam kebijakan legislative di Indonesia, (Tesis). Semarang: Universitas Diponegoro

Irawan.,Prasetya, 2006, Materi pokok metode penelitian administrasi. Jakarta : Universitas terbuka.

Muladi dan Barda Nawawi Arif., 2010, Teori-teori dan kebijakan pidana, Bandung: Alumni.

Pujiyono, 2007, Kumpulan tulisan hukum pidana.Bandung: Mandar maju

Setiady, Tolib., 2010, Pokok-pokok hukum penintensier Indonesia, Bandung: Alfabeta.

Sudarto, 1990, Hukum pidana I, Semarang: yayasan Sudarto.

Supanto, 2008, Kebijakan Formulasi Hukum Pidana ekonomi dalam menghadapi globalisasi ekonomi,(Disertasi). Semarang: Universitas Diponegoro

Syahroni, Rambe Rahmad, 2014, Kebijakan Formulasi ketentuan pidana terhadap tindak pidana pencurian di Indonesia,(Tesis). Semarang: Universitas Diponegoro 